DOI: https://doi.org/10.24144/2409-6857.2018.2(52).138-143

JEL Classification C 42, L 96, M 31

Striy L., Stankevich I., Agamedova L.

\title{
THE MODERN MARKETING ENVIRONMENT OF THE AZERBAIJANI TELECOMMUNICATION ENTERPRISE
}

\begin{abstract}
The purpose of the article is the study of the current state of the marketing environment of the telecommunications enterprise of Azerbaijan and the research of certain factors of the microenvironment, whose influence in recent years has changed significantly: consumers, competitors and a competitive environment; state regulation of the telecommunication services market and management of telecommunications enterprises. The article proposes a scheme of a competitive network model of the telecommunications services market in Azerbaijan. The article also compiled a diagram of the competitive network model of the telecommunications services market in Azerbaijan. The study of the model was carried out by calculating the Herfindahl-Hirschman index, which showed that the market of telecommunication services in Azerbaijan can be considered a potentially competitive market, the competitive environment is developing in the direction of free competition.
\end{abstract}

Key words: competitive market, competitive environment, Herfindahl-Hirschman index, marketing, marketing environment, survey methods, state regulation, micro model, telecommunications, telecommunications enterprise.

Introduction. In Azerbaijan, conditions have been created in the telecommunications services markets that meet the requirements of a competitive market: entry barriers and barriers to competition are legally removed; operators with different forms of ownership of several states operate freely. In a competitive market, those enterprises that use investigated in the work of N. Reznikova \& E.

Kukharenko [2]. The modern marketing environment of telecommunications enterprises in Ukraine has efficient methods of economic activity are more successful and are able to adapt quickly to real market conditions. In these conditions, Azerbaijan's telecommunications enterprises are trying to use modern marketing tools that allow them to continuously study the market situation and react in a \& A. Sakun in the article [3]; O. Rustamov's monograph explores the functioning of the market of telecommunication services of Azerbaijan in the characteristic of factors that continuously affect the market activity of the enterprise, i.e. factors of the timely manner to changing it. This is especially

(C) Striy, Lyubov Alekseevna, Doctor of Economic Sciences, Professor, Professor of the Department of Management and Marketing, O.S. Popov Odessa National Academy of Telecommunications, Odessa, E-mail: striyla@ukr.net, ORCID ID: http://orcid.org/0000-00034683-1806

Stankevich, Irina Vladimirovna, Doctor of Economic Sciences, Associate Professor, Head of the Department of Management and Marketing, O.S. Popov Odessa National Academy of Telecommunications, Odessa, E-mail: arnika@ukr.net, ORCID ID: http://orcid.org/0000-00033937-9145.

Agamedova, Leila, Student, O.S. Popov Odessa National Academy of Telecommunications, Odessa, E-mail: striyla@ukr.net marketing environment of the enterprise. However, scientific research in this direction is clearly not enough. The dynamics of changes in the influence of the factors of the modern marketing environment on the results of the market activity of the enterprise of telecommunications of Azerbaijan has not been practically studied. This determines the relevance of this problem and, accordingly, the topic of the article.

Literature review. The problem of the influence of factors of the marketing environment on the results of the market activity of the enterprise is considered in the work of F. Kotler \& K. Keller [1]. Factors of the marketing environment with reference to the conditions of infocommunications in Russia are been studied by L. Striy, A. Golubev, L. Zakharchenko

period 1997-2012 years. [4]. In the monograph of L.Striy, M. Mamedov \& O. Rustamov presents scientific materials reflecting changes in the marketing activities of infocommunication

enterprises that have occurred in recent years [5]. However, the real situation in modern markets is changing rapidly. Many changes, in particular, related to the influence of the factors of the marketing environment on the results of the economic activity of the telecommunications enterprise in Azerbaijan, are not yet reflected in available publications.

Methodology of the research. The research was carried out by studying and analyzing (in accordance with the purposes of the article) monographs, scientific books, scientific articles, accessible Internet publications, and also by using the results of the authors' own research. The official documents used during the research are statistical data of the State Statistics Committee of Azerbaijan, information published on official websites of the Ministry of Transport, Communications and High Technologies 
of the Republic of Azerbaijan and the International Telecommunication Union. To ensure the validity of research results, the following methods were used: survey methods in studying the current state of the marketing environment of the enterprise; a logical analysis in the study of microenvironment factors of the telecommunication enterprise; method of modelling when drawing up the scheme of a competitive network model of the telecommunication services market in Azerbaijan.

Article purpose. The authors have set the task of this article:

- examine of the current state of the marketing environment of the telecommunications enterprise in Azerbaijan;

- investigate of the some microenvironment factors whose influence has changed significantly in recent years: consumers, competitors and a competitive environment; state regulation of the telecommunications services market and management of telecommunications enterprises.

Presentation of the main research data. The sphere of communication of Azerbaijan is a stable branch of the country's economy, the development of which is given priority by the leadership of the country. The incomes of telecommunications enterprises are increasing at approximately constant rates. The average annual growth rate of income in the ICT sector is $20-25 \%$. In the last 10 years, the incomes of the sector's enterprises have doubled every three years. The rate of incomes of enterprises and key indicators are growing faster than the average in the world and faster than in developing countries. The share of the private sector has increased to $80 \%$. Much attention is paid to the development of marketing [7].

General characteristic of the marketing environment of the telecommunication enterprise. The marketing environment is usually understood as the set of active agents, factors and forces acting outside the enterprise that affect the ability of the enterprise (in this case, the telecommunications enterprise) to establish and maintain mutually beneficial relations with consumers. Factors of the marketing environment can significantly limit the capabilities of the enterprise. It can bring surprises and heavy blows. Changes that occur in the marketing environment are often unpredictable, they introduce significant uncertainty in the management of the enterprise. Continuous research of the marketing environment, if possible, a more complete account of the impact on the company of all its factors is one of the conditions for the success of the enterprise in modern markets [9, pp. 72-73].

Detailing the composition of the marketing environment of the enterprise in general form is carried out in many works on marketing, therefore within the framework of this article it is not appropriate to repeat the training materials. Scheme of the marketing environment of the telecommunications enterprise, which takes into account the specifics of economic activity in telecommunications, is shown in Fig. 1.

Factors of marketing macroenvironment

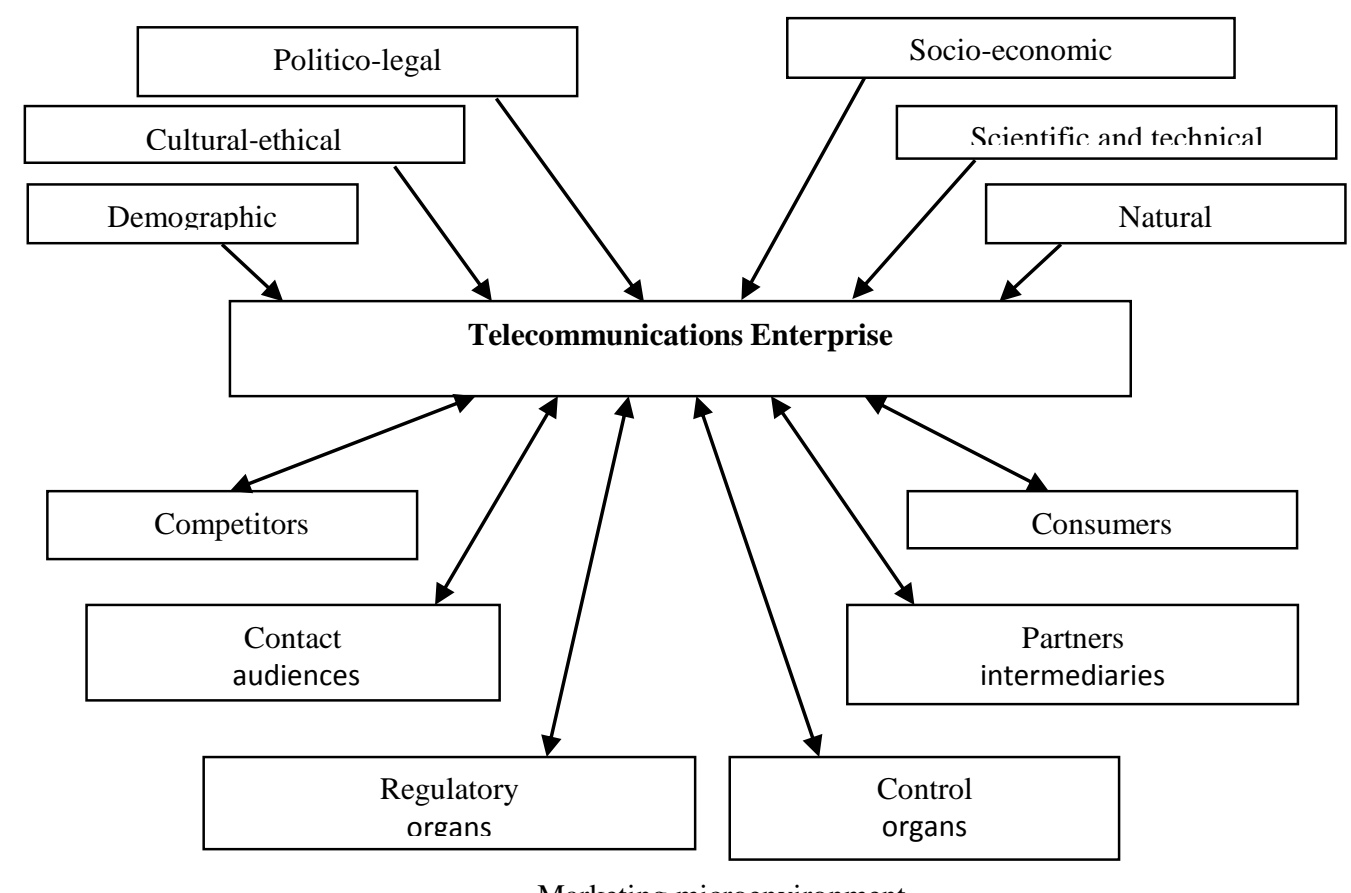

Marketing microenvironment

Figure 1. Scheme of the marketing environment of the telecommunications enterprise* *Source: the authors own development 
The marketing environment consists of the macroenvironment and the microenvironment.

The macroenvironment includes political, legal, demographic, socio-economic, scientific and technical, natural and cultural-ethical factors. The current state and development tendencies of the marketing macro environment were analyzed in detail by F. Kotler \& K. Keller [1, pp. 90-102].

The marketing microenvironment is directly connected with the activity of the enterprise. The marketing microenvironment is the enterprise itself (its internal environment) and its immediate environment: consumers, competitors, partners, intermediaries, contact audiences, control and regulatory organs. The elements of the marketing microenvironment are discussed in detail in $[9, \mathrm{pp}$. 50-53; 5, pp. 74-79].

In the future, in this article, only those elements of the marketing microenvironment that are specific to the conditions of the modern enterprise of investigated in more details: consumers, competitors;control and regulating organs.

Investigation of factors of marketing microenvironment of telecommunication enterprises of Azerbaijan. In this article, only those elements of the marketing microenvironment that are specific to the conditions of the modern enterprise of telecommunications of Azerbaijan will be investigated in more details:

- consumers;

- competitors;

- control and regulating organs.

Consumers. Consumers for telecommunication enterprises are:

- individual consumers who use telecommunications services for their own needs;

- corporate customers who purchase services to solve the production needs of their enterprise;

- organizations, institutions, services, state bodies, military units and all other bodies of the state.

The study, conducted in 2016 year by the Internet provider Q Telekom, showed that $50 \%$ of the company's clients are engaged in business, $25 \%$ are students, $15 \%$ are pupils and $10 \%$ are retired. $60 \%$ of customers are under 30 years old.

Thus, consumers of telecommunications enterprises are the entire population, all state bodies, which ensures the mass character of the needs for telecommunications services and the increased requirements for the quality and forms of providing these services.
Competitors. Studies, the results of which are published in works of Rustamov, Mamedov, Striy, Tolkachova, Golubev, Rzaev [4, 5, 11], allow us to conclude that the telecommunications enterprises of Azerbaijan operate on the telecommunications services market with developing competition.

There are three segments in the market of telecommunications services in Azerbaijan:

- the segment of fixed-line enterprises;

- the segment of mobile enterprises;

- the segment of other enterprises.

The segment of fixed-line enterprises. In this segment communication services are provided by the following enterprises: Aztelekom Production Association; Production Association "Baku City Telephone Network" (BCTN); telephone communication operator of the Nakhichevan Autonomous Republic; four non-state operators. The first two enterprises are state monopolies, the market share of other enterprises is insignificant. The Aztelekom occupies $57.4 \%$ of the fixed-line services market; BCTN - 30.1\%; other fixed-line enterprises $-12.5 \%$. The segment of fixed-line enterprises occupies a share of $18.2 \%$ on the market of telecommunications services in Azerbaijan. Therefore, the share of fixed-line telecommunications in the country's telecommunications market is: $10.44 \%$ for Aztelekom; BCTN - 5.48\%; other fixedline enterprises $-2,28 \%[6,7]$.

Mobile telephone connection. There are four main operators in the mobile communication market: Azercell, Bakcell, Azerfon and Nar Mobile and two CDMA operators: Catel and Aztrank. The main operators occupy the following segments of the mobile communications market: Azercell - 43\%; Bakcell - 27.5\%; Azerfon - 21\%; other mobile enterprises $-8.5 \%$. The segment of mobile communication enterprises occupies a share in the telecommunications services market equal to $77.6 \%$. Therefore, the share of mobile communication enterprises in the country's communications market is: Azercell - 33.37\%; Bakcell - 21.34\%; Azerfon $16.3 \%$; other mobile communication enterprises $6.59 \%[6,7]$.

Other enterprises that are not included in fixed and mobile segments occupy a segment equal to $4.2 \%$ [6, 7].

The scheme of the competitive network model of the communication services market in Azerbaijan is shown in Fig. 2. 


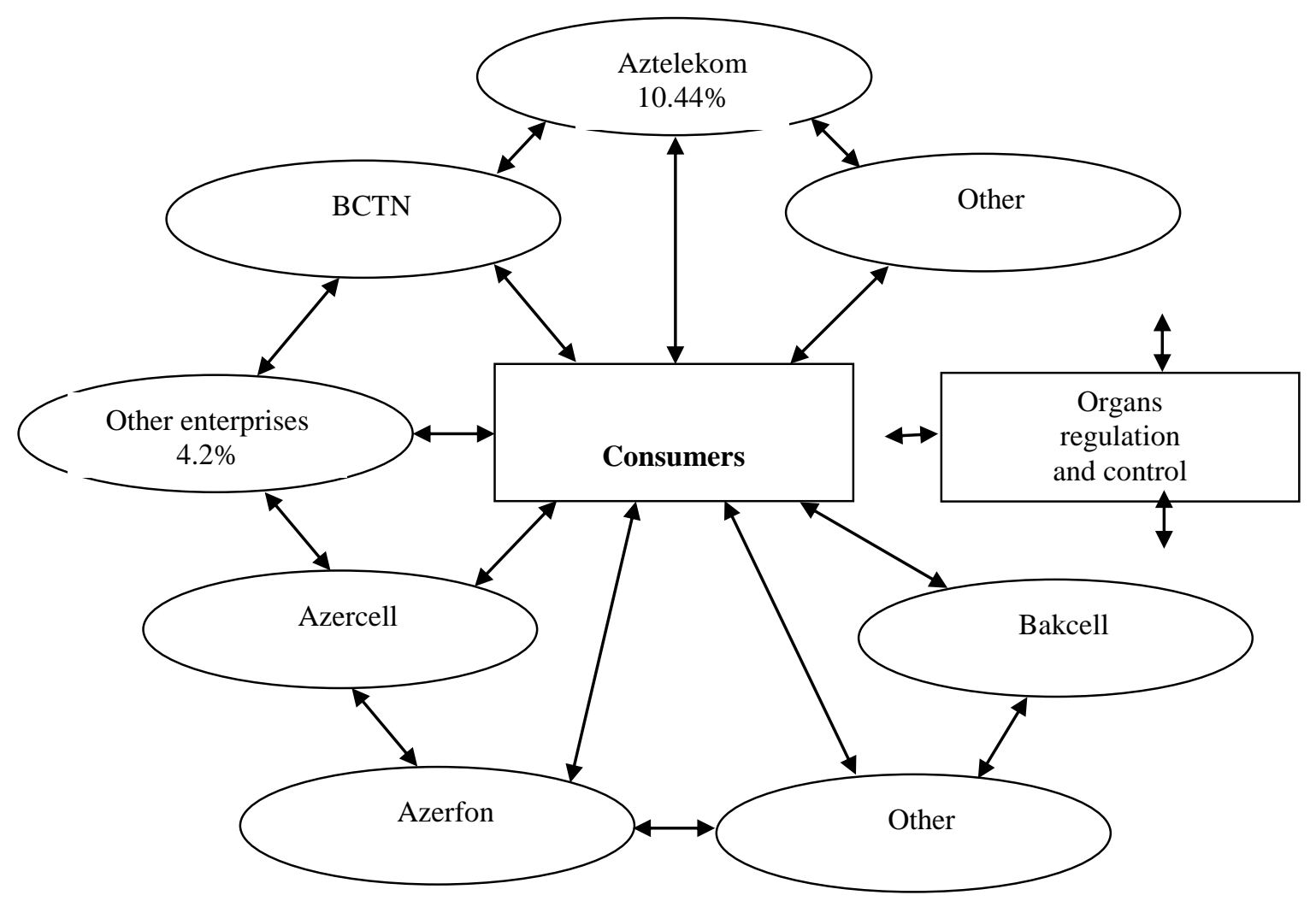

The segment of mobile enterprises $(77,6 \%)$

Figure 2. Diagram of competitive network model of communication services market in Azerbaijan*

*Source: authors own development based on data [6,7].

The level of competition in the market of telecommunications services can be estimated by calculating the Herfindahl-Hirschman index $(I H H)$, which characterizes the level of monopolization of the market, defined as the sum of the squares of market shares occupied by each of its participants, according to the methodology proposed by Professor V. Granaturov in the monograph "Analysis of the competitiveness of telecommunication services" [11, pp. 51-58].

To assess the compliance of the competitive environment of a particular market model, the following numerical values of this index are used: if $I H H=10000$, then the competition state corresponds to the market of pure monopoly; if $1800 \leq I H H$ $\leq 10000$, then the market can be considered potentially competitive; If $I H H<1800$, there is free competition on the market [11, pp. 51-58].

In this case, all the enterprises shown in Fig. 2, competitors and occupy the following market share of communication services $(10.44 \%, 5.48 \%, 2.28 \%$, $33.37 \%, 21.34 \%, 16.3 \%, 6.59 \%, 4.2 \%)$.

Calculations show

$$
I H H=
$$

$10.44^{2}+5.48^{2}+2.28^{2}+33.37^{2}+21.34^{2}+16.3^{2}+6.59^{2}+4.2^{2}$ $=2043.27$
In this case, the value of the index IHH is 2043, the market of communication services in Azerbaijan can be considered a potentially competitive market.

The value of $I H H=2043$ is fairly close to 1800 , so the competitive environment develops in the direction of free competition.

Thus, the analysis of competitors in the marketing microcosm of the enterprise of telecommunications of Azerbaijan showed that marketers and management of a telecommunications enterprise should give priority to studies of competitors' activities, apply effective competitive strategies and continuously adapt them to the changing conditions of a competitive market.

Control and regulatory organs. In Azerbaijan, the Ministry of Transport, Communications and High Technologies of the Republic of Azerbaijan is responsible for control and regulating the activities of communication industry enterprises. In its activities, the Ministry is guided by the Constitution of the Republic of Azerbaijan, international treaties to which the Republic of Azerbaijan has joined, laws of the Republic of Azerbaijan, decrees and orders of the President, resolutions and decisions of the Cabinet of Ministers [7]. 
In telecommunications, the tasks of governance and regulation are established by the Law of the Republic of Azerbaijan "On Telecommunications". This law establishes legal, economic, organizational bases of activity in the field of telecommunications and regulates purposeful planning and fair expenditure of telecommunication resources. The law defines: basic principles and directions of activity of telecommunications; objects and subjects of telecommunications; organization of regulation in telecommunications [7].

Regulation of telecommunications in the Republic of Azerbaijan is in the competence of the state and is carried out in the following areas [7]:

- organization of using the numbering resource;

- Licensing of telecommunications activities;

- certification in the field of telecommunications;

- application of tariffs for telecommunications services and the use of radio frequencies;

- regulation of a healthy competitive environment and antimonopoly activities in the telecommunications sector;

- Organization of the use of radio frequencies;

- regulation of mutual interconnection between operators;

- other directions on regulation, established by the legislation.

Experience in the practical application of this law has shown that combining the tasks of control and regulation in one organ does not contribute to ensuring the required efficiency of telecommunications enterprises in a competitive market. Currently, research is being conducted aimed at creating a separate independent regulatory organ.

Conclusions and prospects. The conducted research of the state of the marketing environment of the telecommunications enterprise of Azerbaijan allows to formulate the following conclusions.

1. Modern market relations have been formed in the telecommunications sector of Azerbaijan. The industry successfully contributes to the formation of a knowledge-based economy by developing ICTs and fully satisfying the needs of society in information products and services. Significant steps have been taken in Azerbaijan to develop telecommunications and information technologies, and some progress has been made in this direction. The ICT sector was declared second in priority after the oil industry.

2. The article presents the scheme of the competitive network model of the market of telecommunications services in Azerbaijan. The study of the model showed that the market of telecommunication services in Azerbaijan can be considered a potentially competitive market, the competitive environment is developing in the direction of free competition. Therefore, marketers and managers of a telecommunications enterprise should pay should give priority to research of competitors' activities, apply effective competitive strategies and continuously adapt them to the changing conditions of a competitive market.

3. In Azerbaijan, the tasks of control and regulating the activities of communication industry enterprises are assigned to the Ministry of Transport, Communications and High Technologies of the Republic of Azerbaijan. The combination of control and regulation tasks in one organ does not contribute to ensuring the required efficiency of telecommunications enterprises in a competitive market. Currently, research is being conducted aimed at creating a separate independent regulatory organ.

The originality of the results lies in a detailed study of the real directions of changing the microenvironment factors in modern conditions, as well as in developing a scheme for a competitive network model of the telecommunications services market in Azerbaijan.

Further research on this problem can be directed to detail the changes in the marketing environment that are necessary for the successful performance of tasks by the telecommunication sector in the process of implementing the National Strategy for the Development of the Information Society in the Republic of Azerbaijan for 2016-2020 years.

\section{REFERENCES:}

1. Kotler, F. \& Keller, L., (2014). Marketing menedzhment [Marketing Management] (14nd ed., rev.). St. Petersburg: Piter [in Russian].

2. Reznikova, N. \& Kukharenko, E., (2013). Marketing v otrasli infokommunikatsiy [Marketing in the infocommunications industry]. M.: Goryachaya liniya-Telekom [in Russian].

3. Striy, L., Golubev, A., Zakharchenko, L. \& Sakun, A. (2016). Sovremennaya marketingovaya sreda predpriyatiya telekommunikatsiy Ukrainy [The modern marketing environment of the enterprise of telecommunications of Ukraine]. Molodoy vcheniy: [Naukoviy zhurnal]. Kherson: - Vidavnichiy dim "Gel'vetika". Vol. 9 (36), pp. 30-34.

4. Rustamov, O., (2012). Adaptatsiya upravleniya predpriyatiyami k sovremennym usloviyam konkurentnogo rynka: monografiya [Adaptation of enterprise management to modern conditions of a competitive market: monograph]. Baku: Mars Print [in Russian].

5. Strii, L., Mamedov, M., \& Rustamov, O. (2015). Marketing predpriiatii infokommunikatsii: sovremennye vidy marketingovoi deiatel'nosti: monohrafiya [Marketing of infocommunication enterprises: modern types of marketing activities: Monograph]. Saarbrucken: LAP Lambert Academic Publishing [in Russian]. 
6. The State Statistical Committee of the Republic of Azerbaijan. Official site. Access mode: https://www.stat.gov.az.

7. Ministry of Transport, Communications and High Technologies of the Republic of Azerbaijan. Official site. Access mode: http://www.mincom.gov.az/en/.

8. International Telecommunication Union, ITU. Official site. Access mode: http://www.itu.int.

9. Striy, L. (2000). Marketingovoye upravleniye na rubezhe XXI stoletiya: monografiya [Marketing management at the turn of the 21st century: monograph]. Odessa: Astroprint [in Russian].

10.Striy, L., Tolkachova, G., Golubev, A. \& Rzaev, N. (2017). Adaptation of the economic activity of a telecommunications company to the conditions of a competitive market. Development strategy of science and education: Collection of scientific articles. Fidelite editions, Namur, Belgique, pp. 126-132.

11. Granaturov, V. \& Vorobienko, S. (2009). Analiz konkurentospromozhnosti telekomunikatsiynykh posluh: monohrafiya [Analysis of competitiveness of telecommunication services: monograph]. Kiyev: «Osvyta Ukrayiny» [in Ukrainian].

Одержано 30.08.2018 p. 